\title{
Ethnographic Presentation of Speaking in Chamber
}

\author{
Phd. Emin Krasniqi
}

\section{Doi:10.5901/ajis.2015.v4n2p313}

\section{Abstract}

Every situation of discourse (Rugova,1978:126), either implicit or explicit, expresses its categories of grammatical, semantic and pragmatic values. Speaking situations in the chamber, (oda) in many planes, are typical and characteristic only for the category of interlocutors in this environment. The discourse differs from discourse (telling) and the other categories: speaking in chapel (church and mosque), in the case of the celebrations, marriage acts, inauguration and the written speech. In this discourse are included complexes of interactive rates and socializing means of social interaction, which define "scene", define "context and are obtained from the " referent ". Situations of speech, are ways and means of expression of the statement, but, even the suppression against the word ,is social competence of communication and Intelectology ( Ismajli, 1994:141).

Keywords: Ethnography of speaking, group speakers, Chamber of men, representative selection of speakers, speaker status.

Speaking situations in the chamber, from greetings to the goodbyes are ceremonial acts. This talk is cognitive in appearance (canonical), which typifies situations by "enter"; in keeping suppression word to word up to "exits", transmission of the words at the others.

The distinctive value of speaking situation, of frame, referent and scene, in the ethno-cultural environment are:

\section{Selection of Speaking Space}

Beforehand, the background of the speaking space is selected. A preferred physical environment of each home, as the Chamber of men or a space-speaking background (log, square, meadow, fountain) in which can be lived in and the work can be done comfortably. The nature of this environment reflected the ethnological and ethnographic garb, which was functionalized from thematic diversity and was institutionalized with the social role of the speaker.

\section{Selection of Representative Speakers}

From a sociolinguistic perspective, the selection of the speakers includes :

1. Aspects of the vertical plane:

(a) The speaker (listener) had the status of organizing the social environment, (who speaks?); iii. These interlocutors expressed "power and language solidarity" iv. Aspects of the horizontal plane:

(a) The subjectivity of the speaker (listener) noting solidarity (with personal pronoun: you> <you), power (you> <you) and a different status (you> <you), power (you> <you) and (you,> <you, etc.); (listener): (to whom do you speak?)

(b) The Register implemented by the speaker, linguistic facts: phonological, syntactic and lexical, intonation, redundancy, variables (when, where and what (variety) speaks?).

\section{Participation of Interlocutors}

Interlocutors, primarily, were equal, in debates and decisions, but were seen ternary:

1) On the level of organization and social and economic representation (To anyone rich, Kaçak ( a a mountain men) or power man was told: Oh, welcome and may God bring you (adaptability); For anyone did not represent any high degree or economic organization was told: Oh, come on, come on ...! (others whispered): May not never come !

For anyone who was jocular when he called: Are you there?, It was said: Yes, yes! Chamber (oda) is for all! Sit down. Others said Even for you. Participant subjectivity speaker (listener) contains markers of the relationship, the structure and content (where, when speaking?); 
1) From the age, physical maturity and mindset, as children: no guy can not even enter into this environment; boys only served participants;

2) From the affiliation of natural gender (sex). Females could participate and had the right of speech if they represented the chimney or the flag;

\section{The Physical Distance between Interlocutors}

Participants in this institutionalized environment had a certain physical distance, depending, on the relations in society. Interlocutors stood side by side and faced each other in a distance of several (two to five) meters, depending on the area. Naturally, all were together and, at the same time, facing each other. The relationship between speakers was defined and evaluated by the distance between them (Drançolli, 2001:214).

\section{The Physical Position of the Speakers (Listeners)}

For these environments, the staying position of the speakers (listeners) reflected their culture. The main indicator of staying was intrapersonal behavior and one of the indicators of interpersonal social environment, of speakers, themselves. ( Doli, 2001:139). These are some ways of staying, sitting which showed some of the characteristics of the person. For example:

- Staying cross-legged with arms put on the knees with the index finger of one hand (either left or right) biliary (restrained man, calm and meditative);

- Staying on knees ( pompous man who seems "great");

- Staying with one leg, with folded knee (man, carefree, non concentrated, who sits " ready to take the word and then to decide");

- Staying with half folded leg and crossed hands folded on the knees (attitude characteristic for women, the man who sat this way was called: slut, spoilt, hooker, etc.);

- Staying with outstretched legs and leaning against the wall (read: he is nowhere, he could not get out the cat from mash);

- Staying half lying, leaning on one side (for this way of staying, were given two trials: if, the man was suffering from back pain it was told: "May God help!"; if the person was standing because of his weight, he was told: His mind has gone to the stomach

- Staying lied (was allowed only to old (white bearded) man who either older or were known for their intellect . On the contrary, for the man who stood in this way was told: "He looks like a woman after childbirth!);

- Staying on the knee (was said for a spoilt, tricky, who had his minds over the hood!";

- Staying at the top of the backside one leg over the other (man, pompous man, vicious)

\section{The Direction of the View by the Speaker (Listener)}

In whatever situation of discourse, the direction of the view is an indicator of the relationship structure and content. Direction of view by the speaker (listener), expresses nominating relationship and semantic: solidarity, power, distinctiveness. The action of viewing, points out "factual language function. Direction of view by the speaker (listener), in these environments was an implicit, connotative, intrapersonal (Radovanovic, 1986: 53) interaction socializing tool. As a result of viewing direction we have the sayings: Wait that I want to speak, ok!? Why are you looking at me? What do you want (-)?! Where do you go? Don't you like to stay? Don't you like the conversation If you find anything better, call me too!, I am talking, ok!?,, Look at my eyes!",, Do not hang your head down!"

,.,Who is honest looks you in face! ",A real man does not wink the others!! ,. Only (betrayer), does not look in your eyes", ," A man does not play with his hands," Ok, ok if you find crumpet call us! He wasn't scared at all! He did not look at him! Viewing direction is a set of non- verbal situations. In order to analyze the factual view of the visibility we should have a multidisciplinary approach: sociological, psychological, pathological, neurological, physiological, technological. 


\section{Selecting the Words of the Speaker (Listener)}

From the historical perspective (Ethnological), all those who pretended to appear in the Chamber of men had, previously, to pass a series of tests. The Chamber of men, over time, was a natural environment and institutionalized of the submission and review, submission and solution of the problem, but even of the competition and interpersonal values. Given the indicators of the presence of cognitive and expressive world, the speaker (listener), interlocutors and relevant speakers, regarded the spoken word as highly important. ("As said, will be done! As said, was made ", For any words that was precious among the men should think better",,., A man should have clear words( as a foil stone) that are important when he speaks ",, We are so glad(with all our relatives) with friends, Godfathers and kith (Drançolli, 2004:91).

\section{Speaking and Referring from the Speakers}

Speaking in the discourse is the system of codified language.

It is the determined register of language and speaking networking. Referring is defined by factors of social interaction and cultural interaction speaking community social community, professional groups, social strata and migrations, carried out by the speaker (listener), which selects the set and uses tools of expressive language (performance) in various situations of communication. Each speaker has its own image, which reveals the act of saying, speaker identity, which reflects the relationship (power, solidarity distinctiveness) between interlocutors (cross-speakers). In this relation, the speaker (listener) a interlocutor "must follow a certain order" (Hudson, 2002:149) for all "inputs" and "outputs"7 in the space of this ethno-cultural environment. Referring and speaking (discourse) include a group of spoken layers, from greetings, assignment of roles, submission for solutions, relationship solving until to the farewell: greeting.

\subsection{Greetings}

The person acceptable to the parties or the owner of the house address the opening speech: congratulations, greetings thanksgiving, which expresses full solidarity feelings: Welcome and may God bring you! Oh men! In good situation, in such a chimney and house , since you walked may God bless you! Your honors and efforts only God can repay!, We cannot! If you (and we) enjoyed some of the tribe, kith, godfather and friends!

\subsection{Designation of roles}

Division, determination and choice of roles was the beginning for contexts solutions by and for the represented. In order to choose the representative of the party, a number of old (man) together choose a reeve (Chairman). After the composition of the Reconciliation, the Councils headman that, now represented the environment as well, made the made the presentation of the days issues.

c) Presentation of solutions

Being that the speaker (listener) expressed his entire inner world, it had an ingenious role, he tried to do the selection of the quantity and quality of information, the selection of ways, the selection of norms of socializing tools as well as social interaction. With the implementation of this in the presentation of the speaker (listener) potential tension arousing situations were avoided and, after that, he choose the most appropriate words to deliver the message „, Men! Brothers! Enemies cracked our heart and burned us our soil ".

But let us not break our own arms! Oh God, do not convince anyone" ! Who is killed, May be, forgiven! God forgives his mistakes. May God, make it light! Listen you men! And you brothers! And you dear, that came to condole us always! Brave man, a man of men, said our leader, he forgives the blood of killed male son's blood! I know you too! And you know that we know, Oh man! Your home has been recognized for loyalty all the way to in Shkoder! Whenever bread, trust and bravery was meeded! (Others in the room), Stand up, and stretch out the hand of reconciliation brother! Strong men, like you, can make this! In the chamber rules silence ! Someone stands up. Sees all attendees! Sees the headman. (Nonverbal situation of solidarity). And says: For this world, may be forgiven my brother's and son's blood! (All participants) Aferim! Bravo! Well done, man! (Some) Eh brother! Let be them be blessed always! Only real men like you do this!

d) Solution- Interrelationship

The solution of the conflicts renewed relationships, which hardened with the same feeling of power, solidarity and distinctiveness : Who remembers us, may we see worse and worse!!May not had a well in his home! May do not even 
find seed in his fields Do not even come friends and kith! Let go out and bray as donkeys!"

\subsection{Farewell greeting.}

Separation was rejuvenation and cultivation of relationships. Made with the blessings for the future: May God add you prosperity . For the poor and friend may your doors be always open! May traitors never set foot in the eve of this house! God help us! You even us! Let good! Have a nice journey, men!

\subsubsection{The content of the speech}

The content of the speech was one of the key indicators of the culture of behavior, depending, on the social environment and intrapersonal cognitive world of the speaker.

This stage of communication between speakers (interlocutors) contained mutual combined semantic. The focusing of the speakers in the means and forms of speaking, in the quantity and quality of information, on duality, socializing tools are crucial and should be made in detail, if you want to avoid insulting, shame, and ridiculous situations "( Hudson,2002: 150) . Even the minutest slippage of the speakers toward the listener is accompanied by opposition (intervention): ,, Now I do speak, ok!? To whom are you selling this?! I eat bread as you, not straw Clear your yard once and then ...!;,, Do not point your finger! (I pick off! <I cut your head! <Only your wife can do this, if you have courage, normally!); Why do look at me, balosh (epithet in Albanian) ?! (Do you know me!). Do you think that, I am scaring of you!?, Etc. Possible Meanings create circumstances for a wide array of situations.

\subsubsection{Transmission of the word}

In such ethno cultural environments, , full attention and energy were focused on maintaining entities and identities "bloodlanguage-nation", (Sejdiu,2000:15) because the speakers, generally, were proud of who they were ". The Chamber was held not with meat and pie, but with the order assigned to the conversation. And who did not abide by that order was sent out. So, continued the speeches one by one.( Hudson,2002: 233)

\section{Intonation and Rhythm of Speakers (Listeners)}

Intonation and rhythm of the voice are among the essential indicators of speaking situations, generally.. For example: are you also going with him? (Solidarity, affinity relationships, wish) Are you going? Is it going?! (Power, distinctiveness , relationship, order, threat); Thanks! (Solidarity); Thank you! (creates distance, statutory distinction); Well, good men. We finished this job! (Solidarity) (distinctiveness relation, power. Tense situation in the sense: May be not see each other!); Who is speaking to you (just!) (distinctive relation , because of the nonelection of the alternatives of speakers) To whom are you speaking so? (Distinctiveness and statutory distinction, he does not understand this. The rhythm represents both compliance and non compliance of thoughts with feelings of the speaker (listener) creating escalating ,contagious. and declining situation, .

Intonation, redundancies are attributive notions basic to linguistic ability of social behavior, individual and collective. They are indicative of cognitive and expressive culture of the entity of the individual speakers (listener) at any environment. (Ushaku,2000:227)

\section{Respect and Courtesy of Speakers (Listeners)}

In all physical and institutionalized environments, respect and politeness of the speakers (listeners) are performing functions of courtesy or linguistic hypocrisy. Everywhere across Albanian territories formerly in the cities, people in the street waving are not just acquaintances, but even strangers, who come from surrounding areas or even from far" (Shkurtaj, 2001: 203). In the chamber of men more important was the respect and politeness of nonverbal speakers (listeners) than any words . Respect and courtesy of speakers (listeners) preceded situations during the lecture and the implementation of any agreement (oral or written) between the interlocutors. Cognitive behavioral situations are unique and expressive, because "no semiology of the sound, color and image can be formed in sounds, colors, images. Every semiology of a linguistic system should borrow from the language dragoman that may exist, therefore, it only exists through language and semiology ". Therefore, the speaker, in all the speaking situations, either implicit or explicit , 
includes all components and context of the matrix, cohabiting not in the linguistic contents, but in contexts of speaking situations

\section{Conclusion}

Considering stratified legitimacy between cognitive and expressive world as physical and physiological barriers in the "channel" of communication; recognition, enforcement and implementation of the rules of grammar, opinion and motivation (socio-cultural context) of multiple semantic overtones of receiving statements in different situations speech; legalizing language postulates that ,the number of possible contexts of a statement is infinite, claiming to bring a carry guide (program) telling process which includes: the speaker, the listener, an interlocutor and all other grammatical semantic elements: Time, the place of the modality, the accepted integrative approach of taxonomy and ethnographic description, which will show the effort to observe the statement out of the situation." To justify this, we bring the valorizing conception of phonetician David Abercrombie that "we talk with the vocal organs, but speak with the whole body".(Hudson,1980:154)

Exploring linguistic behavior of individuals in a certain social and institutionalized environment is an ethnographic context, a microsociolinguistic realm. The first trial of a scientific integrated linguistics theory, based on the ethnographic method was applied by Dell Hajmz (1962),, which he called "The ethnography of Speaking".

\section{References}

Benvenist, E. (1980) Problems in general linguistics, Belgrade

Drançolli, F. (2001) Kulla shqiptare, Prishtina.

Dragoti, E. (1999) Psikologjia sociale, Tirana

Doli, F. (2001) Arkitektura tradicionale popullore e Kosovës, Pristina.

Gahagen, J. (1978) Interpersonalno i grupnoponaŝanje, Belgrade.

Hajmz, D. (1980) Ethnography of speaking, Belgrade.

Hudson, R. (1980) Sociolinguistic, Tirana.

Leach, E. (1983) Cultural communication, Belgrade.

Levy-Strauss, C. (1999) Mendim i egër, Peja.

Kant, I. (2004) Themelimi i zakoneve shoqërore, Tirana,

Ismajli, R. (1994) Etni e modernitet, Dukagjini, Peja.

Ismajli, R (1991) Gjuhë dhe etni, Prishtina.

Morris, D. (1979) Detection of Man, through gestures and mythology, Belgrade.

O. Dykro-C. Todorov (1984) Encyclopedic dictionary of discourse science, Prishtinë.

Pettijohn, T. (1996) Psychology, Tirana.

Radovanovic, M. (1986) Sociolingvistika,Beograd.

Rugova, I. (1978) Towards theory, Renaissance, Pristina.Sejdiu, Sh. (2002) Sisteme, struktura, raporte (etnolinguistikë), Prishtina.

Ushaku, R. (2000) Hulumtime etnolinguistike, Prishtina.

Shkurtaj, Gj. (2004) Onomastikë dhe etnolinguistikë, Tirana.

Shkurtaj, Gj. (2004) Etnografi e të folurit të shqipes, Tirana.

Serpel, R. (1978) Uticaj kulture na ponašanje, Belgrade. 
